\title{
Degree of Internationalization, Staff Localization and Bank's Overseas Performance: Evidence from China's Top Four Banks
}

\author{
Li Xiong ${ }^{1}, \mathrm{Ke} \mathrm{Xu}^{1}$, Cong $\mathrm{Hu}^{1}$, Xiaojuan $\mathrm{He}^{2}$ \\ ${ }^{1}$ School of International Business, Southwestern University of Finance and Economics, Chengdu, China \\ ${ }^{2}$ Guobao Life Insurance Co., Ltd. Chengdu, China \\ Correspondence: Li Xiong, School of International Business, Southwestern University of Finance and \\ Economics, 555 Liutai Rd, Wenjiang, Chengdu, Sichuan 611130, China. E-mail: leexiong73@ swufe.edu.cn
}

Received: August 3, 2018

doi:10.5539/ibr.v11n9p119

\author{
Accepted: August 21, 2018 \\ Online Published: August 27, 2018 \\ URL: https://doi.org/10.5539/ibr.v11n9p119
}

\begin{abstract}
In international expansion, staff localization helps Chinese commercial banks to provide services to meet local needs. This paper explores the mediation effect of staff localization and refines the measurement of bank's overseas performance, to reveal the transmit channel of how the degree of internationalization (DOI) affects bank's overseas performance. With data from 2009 to 2015 of China's top five banks as the sample to build a panel data model, the result suggests that staff localization fully mediates the relationship between DOI and bank's overseas performance, and DOI exercises positive effect on the overseas performance of intermediary business, but no significant effect on the overseas performance of deposit/loan business. Implications and suggestions for bank's overseas practice are discussed.
\end{abstract}

Keywords: degree of internationalization, staff localization, deposit/loan business, intermediary business

\section{Introduction}

Along with economic integration, institutional transition, financial liberalization as well as other causes, especially a substantial increase in the presence of foreign banks in China, some Chinese banks expanded their business across borders to increase market share and competitiveness (Chen et al., 2017). Emerging market firms tend to have fewer resources than developed market firms and face greater costs due to weaker competitive environments (Eden \& Miller, 2004; Huang \& Sternquist, 2007; Miller \& Parkhe, 2002). Chinese banks are therefore typically younger and less experienced than banks from developed markets. Chinese banks adapt to the dynamic external environment by staff localization, which can help overcome the disadvantages of operating at a distance and in unfamiliar settings (Hymer, 1976). In this process, the expertise and ideas brought by local employees strengthen the banks' service and innovation ability, thus improving the overseas operation of the banking business. However, the existing literatures mainly focus on the analysis of the direct impact of internationalization degree on bank performance, and rarely consider the transmission path, namely the intermediary role of staff localization.

The current main business of Chinese banks consists of two parts, the deposit/loan business and the intermediary business. Because of the different nature of these two categories of businesses, the impact of local employees on the bank's internationalization process is different. The operation process of the deposit/loan business is similar both in and outside China, and the intermediary effect of local employees is not obvious. Commercial banks in developed countries gradually take the intermediary business as a profit growth point, and both development level and financial innovation ability in intermediary business are continuously deepened. In contrast, Chinese banks now have high repeatability in intermediary business, confined to traditional labor-intensive intermediary businesses, such as settlement, guarantee etc. And because of the lack of domestic ambidextrous talents, Chinese banks are restrained from other knowledge intensive intermediary businesses. But this can be improved by employing local staff in the process of overseas expansion. Therefore, the business philosophy that the banks learn through staff localization when expanding overseas should be mainly used in the intermediary businesses such as investment consultation and financial management. But the existing literature generally studies the impact of internationalization on the overall performance of banks.

This paper contributes to this stream of research using a large panel of four state-owned commercial banks 
(commonly referred to as the "Big Four" banks), i.e., Bank of China (BOC), Agriculture Bank of China (ABC), China Construction Bank (CCB) and the Industrial and Commercial Bank of China (ICBC), in the period of 2009-2015. With respect to previous work, the paper attempts to provide a more comprehensive framework, systematically analyzing the relationships among DOI, staff localization and bank's overseas performance, and exploring the mechanism of global expansion on performance. The results show that DOI has a direct positive effect on the overseas performance of the deposit/loan business, but the intermediary role of staff localization is insignificant. However, DOI has a direct positive effect on overseas performance of the intermediary business, and staff localization partially plays a positive mediating effect between the DOI and overseas performance of the intermediary business. At the same time, highly internationalized Chinese banks are more aggressive in promoting staff localization.

The contribution of this paper lies in two aspects: (1) from theoretical perspective, this paper discussed the internationalization of banks from the perspective of organizational change process, with the introduction of staff localization as the intermediary variable and refined the measurement of bank's overseas performance, a new inspection index of internationalization, opening up the "black box" of internationalization degree influencing the performance of a bank. The system investigates the relationship between internationalization degree, staff localization and bank's overseas performance, and reveals the transmission path of the influence of overseas expansion on performance. (2) From practical perspective, either through setting a new branch or taking the path of mergers and acquisitions to promote the international network layout, Chinese banks are to participate in the competition under the background of marketization. China's accelerating interest rate liberalization reform process has forced banks to shift from a single profit model on net interest margin to a breakthrough in the search for differentiated management. This paper from the perspective of the organizational change, analyzing Chinese banks' path of resorting to staff localization to develop intermediary business and affect the performance of the path, has certain guiding significance to other banks' overseas expansion behavior.

The remainder of this paper is arranged as follows: the second part is the literature review; the third part is theoretical foundation and research hypothesis; the fourth part is research design; the fifth part is the empirical result; the sixth part is endogeneity and robustness test. Finally, this paper concludes.

\section{Literature Review}

\subsection{Internationalization and Performance of Bank}

Domestic and foreign scholars mainly study the relationship between internationalization and bank's performance from two perspectives.

One is to explore the causal relationship between internationalization and bank performance. Walid and Eric (2009) argue that the existing literature in international business, exploring the relationship between DOI and performance, assume the implicit assumption that DOI has a direct impact on bank performance, and ignore the fact that banks have advanced technology and products, and good performance in the domestic market, which tend to expand its market share in order to increase profit by overseas expansion. The second is to analyze the direct impact of internationalization on bank performance (e.g., Xiong et al., 2014; Liang et al., 2013; Wan et al., 2008).

Currently, domestic and foreign research on the internationalization degree and bank performance concentrates only on the degree of internationalization, a direct impact on the performance of banks without taking into account the transmission path, namely the intermediary role of the staff localization. The relationship between internationalization degree and bank performance cannot be further explored from the perspective of direct impact which only studies the effect of internationalization on the overall performance of Banks. As for how Chinese banks acquire the experience and ideas, as well as which type of business the experience and ideas are applied to so as to realize the change of bank overall operating performance, there is little literature analysis in-depth.

\subsection{Staff localization and Performance}

For the relationship between localization and performance, the existing literature mainly from the perspective of human resource management analyzes the performance influence of multinational companies in China implementing localization (e.g., Wei \& Zheng, 2010; Jing, 2011), and pays less attention to the localization behavior of Chinese enterprises in overseas, nor does it study the improvement of business operation ability from the localization of employees. The research samples includes various industries, but the business operation of the bank is significantly different from that of other industries, so it is necessary to analyze the influence of the localization of the employees on the bank's performance separately. And the localization is considered to be less 
of an intermediary variable. Taking the subsidiaries established by multinational companies in China as examples, Ye (2010) introduces the localization strategy as the intermediary variable to analyze the relationship between enterprise competence and performance.

\subsection{Measurement of DOI and Performance}

\subsubsection{DOI}

The contents of DOI include business, institution, equity, management, human resources and supervision, and the contents of these five aspects are generally carried out in practice (Guo, 2008). The selection of measure of internationalization degree mainly focuses on three aspects of business, organization and human resources. These include a single index and a composite index. In the single index, the most widely used is the degree of internationalization of foreign assets and their accounting representatives on behalf of commercial Banks (Feng \& Ouyang, 2003).Among the composite indicators, the most representative is the transnationality index, which is the average value of overseas assets, overseas operating income and overseas employees.

\subsubsection{Performance Measurement of Commercial Banks}

There are many ways to measure the performance of commercial banks. The currently widely-used are Tobin Q value, Return on Assets (ROA) and other single financial indicators as well as comprehensive consideration of various indicators. Through comparative analysis of the measure of scholars both at home and abroad it can be found that for most foreign scholars the Tobin $Q$ value is used to measure the performance of commercial banks (Liang et al., 2013), and a few use the Return on Assets as a performance measure (Andres \& Vallelado, 2008; Walid \& Eric, 2009). But the Tobin Q is the ratio of market cap to book value. So it can only be used to measure the performance of listed companies, and the shares of listed companies is changing at any time, Thus price fluctuation must be taken into consideration in the empirical research, which leads to more complexities when specifying the values.

The most widely used measure by domestic scholars are the Return on Assets and other single financial indicators (e.g. Sun et al., 2006; Wang et al., 2012). However, the single financial index cannot comprehensively evaluate the performance level of commercial banks, which can only partly reflect the operation condition of the banks. There are also some studies using a combination of various financial indicators (e.g. Qi, 2008; Liu et al., 2012). Although there are many ways to measure the performance of commercial banks, they have their own shortcomings. And there is no universally accepted approach.

\section{Theory and hypotheses}

\subsection{DOI and Overseas Performance}

"Follow clients from home country" is one of the biggest motivations for the internationalization of Chinese banks (Deng, 2008; Liu, 2007). Aliber (1984) argues that, to avoid losing customers, banks will expand their business overseas in order to provide payment settlement and trade financing facility to cooperate with the foreign direct investment or trade behavior of home country's clients. Based on the long-term relationship with domestic banks, multinational companies would also be more inclined to handle the deposit/loan business in the familiar home country's banks in the process of opening up overseas markets. Therefore, it is the profit point and foothold of the internationalization operation of Chinese commercial banks to carry out the deposit/loan business with overseas clients from motherland. However, in the international environment, Chinese banks have not yet completed the global network layout and with their limitation of size, making Chinese multinational companies more likely to choose large multinational foreign banks with wider distribution. Along with the increase in setting up branches overseas and the DOI, the gap between Chinese banks and foreign banks will be narrowed. So they're able to maintain and consolidate home country's existing customer base, and then improve deposit/loan business internationalization performance. This leads to the following hypothesis:

Hla: The higher the DOI, the better the performance of its overseas deposit/loan business.

In the international business environment, with interest rate marketization, Chinese banks lost their profit margins, thus improving their dependence and focus on intermediary business (Wang \& Feng, 2007). And the change of rivals has forced Chinese banks to compete closely with big foreign multinational banks. Large foreign multinational banks tend to have stronger market researchand new products development capabilities. Their quality and diversity of service in intermediate business have brought great challenges to Chinese banks. According to the market competition effect, this will force Chinese banks to improve their own intermediate business level (Huang, 2011). Baum and Ingram (1998) believe that enterprises can acquire new knowledge by organizing external learning, namely, by observing and imitating products and processes of other successful enterprises. While the research and development of the technology-intensive intermediate business products of 
large foreign banks is expensive, due to the strong replication and portability of technology spillovers and with the deepening of internationalization, Chinese banks can improve overseas performance of intermediary business by emulating the types of technology-intensive intermediate business. We therefore propose the following hypothesis for testing:

\section{H1b: The higher the DOI, the better the performance of its overseas intermediary business.}

\subsection{DOI and Staff Localization}

According to the theory of organizational development, changes in the external environment can prompt changes in the organization itself. In the process of bank internationalization, the bank adjusts and improves its function and structure in time to adapt to the local operating environment of the host country as soon as possible. Recruiting local employees is one of the bank's initiatives. Since banks provide credit service, local staffs are more likely to obtain host country's customers' trust. Thus banks can establish good image of Chinese banks in the host country by increasing the employment rate of the host country (Jing, 2011). The deepening of the banks internationalization means that banks need to face more different types of external operating environment, thus promote the behavior of recruiting local employees. The following hypothesis is then proposed:

\section{H2: DOI has positive impact on staff localization.}

\subsection{Intermediary Effect of Employee Localization}

Chinese banks face a very different market environment from their home country when operating a deposit and loan business. Therefore, the Chinese Banks initially can absorb and learn from the experience of overseas operation and deposit and loan business through the localization of employees. But because of the deposit and loan business is a bank's routine business, the degree of homogeneity management is much high. And, with the deepening of internationalization, business management concept brought by the new recruitment of local staff also won't have significant difference. Therefore, the impact on the internationalization performance of the deposit and loan business will not be significant.

The degree of homogenization is high in intermediary business of Chinese banks, only limited to labor-intensive traditional intermediary business, including payment settlement, collection and payment, etc. One of the reasons is that the lack of domestic talents restricts the high value-added type of intermediary business development (Chen, 2015). After all in the intermediary business, technology-intensive intermediate business products are easy to imitate, but knowledge-intensive intermediary business, such as cash management, asset management, and financial advisers can be expanded only through the introduction of talents or nurture new employees. But it is costly and time-consuming to cultivate employees. Since Chinese banks mainly focus on international financial centers and some economically developed cities when choose their locations overseas, where local employees tend to have abundant financial knowledge and global vision, and also have a comprehensive understanding of the economic situation of the host country. Therefore, in the process of overseas expansion of Chinese banks, these banks hire local staff to improve the intermediary business internationalization performance, namely by influencing the bank behavior of hiring local employees, the degree of internationalization, indirectly affect internationalization of intermediary business performance. We therefore propose the following hypotheses for testing:

H3a: The intermediary effect of staff localization on the relationship between DOI and its overseas deposit/loan business is insignificant.

H3b: The intermediary effect of staff localization on the relationship between DOI and its overseas intermediary business is significant.

\section{Methodology}

\subsection{Variables and Method}

\subsubsection{Variables}

In this paper, we refer to the practices of Andres and Vallelado (2008), Walid and Eric (2009), and Guo (2017), which use the proportion of offshore assets to the total assets of banks to measure the degree of internationalization of the bank, as independent variables. Use the proportion of net interest earned by foreign interests in total operating profit of banks and the proportion of net income of commission on total operating profit of bank respectively, to measure internationalization performance of banks in traditional business and intermediary business, as the dependent variable. The intermediary variable, staff localization, refers to the proportion of overseas employees in the total number of employees in the bank.

For the characteristics of the bank itself, existing literature finds that asset size, capital adequacy ratio and 
non-performing loan ratio are important factors affecting bank performance (Liu et al., 2012; Walid \& Eric, 2009), so this article takes these factors as control variables. Moreover, the four major overseas organizations mainly have business connections with the world financial center and countries with close trade relations with China, so basically include all G20 members. In terms of macro factors, in order to control the impact of the host country's economy on the international performance of Chinese banks, the GDP of the G20 members should be added to the control variables.

The specific meaning of each variable in the model and its calculation formula are listed in Table 1.

Table 1. Variables used in analysis.

\begin{tabular}{|c|c|c|c|}
\hline Category & Index & Symbol & Meaning \\
\hline \multirow{2}{*}{$\begin{array}{l}\text { Dependent } \\
\text { Variables }\end{array}$} & \multirow[b]{2}{*}{ Overseas performance } & PERF_LX & Overseas net interest income/bank's gross operating income \\
\hline & & PERF_SX & $\begin{array}{l}\text { Overseas Net fee and commission net income/ bank's gross operating } \\
\text { income }\end{array}$ \\
\hline $\begin{array}{l}\text { Independent } \\
\text { Variables }\end{array}$ & $\begin{array}{c}\text { Degree of } \\
\text { internationalization }\end{array}$ & DOI & Foreign assets / Total bank assets \\
\hline $\begin{array}{l}\text { Intermediary } \\
\text { Variables }\end{array}$ & Staff localization & YG & Overseas local employee/ Total number of bank employees \\
\hline \multirow{4}{*}{$\begin{array}{l}\text { Controls } \\
\text { Variables }\end{array}$} & Log of total assets & LNZZC & Natural logarithm of total bank assets \\
\hline & Bad Loan Ratio & NPLR & $($ loss loan + doubt loan + secondary loan)/Loan Balance \\
\hline & capital adequacy ratio & CAR & Capital/ Total risk-weighted assets \\
\hline & Log of GDP & LNGDP & $\begin{array}{l}\text { Natural logarithm of GDP of G20 countries } \\
\text { (purchasing power parity) }\end{array}$ \\
\hline
\end{tabular}

\subsubsection{Method}

Using the mediation effect inspection procedure proposed by Wen et al. (2004), this paper tests whether the localization of employees plays a mediating role between the degree of internationalization and the internationalization performance of Bank. The empirical model is constructed in formula (1) to formula (6).

$$
\begin{aligned}
& \text { PERF_LX } X_{i t}=\alpha_{0}+\alpha_{1} D O I_{i t}+\alpha_{2} L N Z Z C_{i t}+\alpha_{3} N P L R_{i t}+\alpha_{4} C A R_{i t}+\alpha_{5} L N G D P_{i t}+\varepsilon_{i t} \\
& Y G_{i t}=\alpha_{0}+\alpha_{1} D O I_{i t}+\alpha_{2} L N Z Z C_{i t}+\alpha_{3} N P L R_{i t}+\alpha_{4} C A R_{i t}+\alpha_{5} L N G D P_{i t}+\varepsilon_{i t} \\
& \text { PERF_LX } X_{i t}=\alpha_{0}+\alpha_{1} D O I_{i t}+\alpha_{2} Y G+\alpha_{3} L N Z Z C_{i t}+\alpha_{4} N P L R_{i t}+\alpha_{5} C A R_{i t}+\alpha_{6} L N G D P_{i t}+\varepsilon_{i t} \\
& \text { PERF_SX } X_{i t}=\alpha_{0}+\alpha_{1} D O I_{i t}+\alpha_{2} L N Z Z C_{i t}+\alpha_{3} N P L R_{i t}+\alpha_{4} C A R_{i t}+\alpha_{5} L N G D P_{i t}+\varepsilon_{i t} \\
& Y G_{i t}=\alpha_{0}+\alpha_{1} D O I_{i t}+\alpha_{2} L N Z Z C_{i t}+\alpha_{3} N P L R_{i t}+\alpha_{4} C A R_{i t}+\alpha_{5} L N G D P_{i t}+\varepsilon_{i t} \\
& P E R F_{-} S X_{i t}=\alpha_{0}+\alpha_{1} D O I_{i t}+\alpha_{2} Y G+\alpha_{3} L N Z Z C_{i t}+\alpha_{4} N P L R_{i t}+\alpha_{5} C A R_{i t}+\alpha_{6} L N G D P_{i t}+\varepsilon_{i t}
\end{aligned}
$$

We conducted the analysis as below: first, we test the significance of formula (1)'s regression coefficient, of which the independent variable is the degree of internationalization (DOI), and the dependable variable is the bank internationalization performance (PERF). If it appears significant, then we move to step 2, otherwise, we stop testing. Step 2: we test in turn the significance of formula (2)'s regression coefficient, of which the independent variable is DOI and the intermediate variable is the localization of staff (YG)., and the significance of formula (3)'s regression coefficient, of which the intermediate variable is staff localization (YG) and the dependent variable is bank internationalization performance (PERF). If both of these two regression coefficients are significant, it indicates that internationalization has impact on bank internationalization performance at least through staff localization. If at least one regression coefficient is not significant, then there is step 3.Step 3: perform Sobel (1982) test. If the result is significant, it indicates that the localization of staff has a mediating effect between internationalization and the internationalization performance of banks, otherwise there is no mediating effect. Repeat the above steps in formula (4), (5) and (6).

\subsubsection{Data and Descriptive Statistics}

There are five large joint-stock commercial banks and some small and medium sized joint-stock commercial banks, such as China Citic bank, China Merchants bank and Guangdong development bank, which have branches overseas. Among them, the five major banks are the main players of the internationalization of Chinese banks, so they are representative samples. Moreover, the overseas branches of the five great banks have a quite scale and the internationalization development stage of the five is more consistent. However, because Bank of Communications hasn't published its local staff recruitment, the paper only selects BOC, ABC, ICBC and CCB, as samples. The top four banks' data from 2009 to 2015 were hand-sorted from financial statements published on 
their official websites. The G20's GDP come from the OECD database. At last a total of 56 samples were obtained from these four banks. Related calculations and charts are completed with the help of Stata13 and Excel. Since there's no data missing, it is considered a balanced panel data.

The descriptive sample data is shown in Table 2.The mean of the proportion of overseas assets is 0.0925 , and it can be shown that the internationalization of Chinese banks is relatively low. Meanwhile, the maximum and minimum values are 0.3038 and 0.0054 respectively, which indicates that there are significant differences in internationalization among the four major banks. The mean of the internationalization performance of the deposit and loan business is 0.0630 , which is higher than that of the intermediate business. This means that Chinese banks are still more dependent on the deposit and loan business than on intermediate business when operating overseas.

Table 2. Descriptive statistics

\begin{tabular}{cccccc}
\hline Variables & Sample & Mean & Std. Deviation & Min & Max \\
\hline PERF_LX & 56 & 0.0630 & 0.0693 & 0.0052 & 0.2195 \\
PERF_SX & 56 & 0.0225 & 0.0276 & 0.0005 & 0.0905 \\
DOI & 56 & 0.0925 & 0.0962 & 0.0054 & 0.3038 \\
YG & 56 & 0.0309 & 0.0444 & 0.0005 & 0.1388 \\
LNZZC & 56 & 16.4970 & 0.2675 & 15.9201 & 16.9719 \\
NPLR & 56 & 0.0135 & 0.0052 & 0.0085 & 0.0362 \\
CAR & 56 & 0.1275 & 0.0131 & 0.0831 & 0.1539 \\
LNGDP & 56 & 11.2221 & 0.0704 & 11.0941 & 11.3278 \\
\hline
\end{tabular}

\section{Results}

After a stability analysis of all the variables in the model using LLC test and IPS test, it was found that all variables were stable at the significant level of $10 \%$. According to the above-mentioned test steps of intermediary effect, all regression models in this paper adopted feasible generalized least squares estimation (FGLS), and "heteroscedasticity-serial-correlation-cross-correlation" steady standard error (Driscoll \& Kraay, 1998).The regression results are shown in Table 3.The Sobel test results are shown in Table 4.

Table 3. Regression Results of All Models

\begin{tabular}{ccccccc}
\hline & $(1)$ & $(2)$ & $(3)$ & $(4)$ & $(5)$ & $(6)$ \\
\hline \multirow{3}{*}{ DOI } & PERF_LX & YG & PERF_LX & PERF_SX & YG & PERF_SX \\
& $0.6105^{* * *}$ & $0.4201^{* * *}$ & $0.5985^{* * * *}$ & $0.2281^{* * *}$ & $0.4201^{* * *}$ & $0.1755^{* * *}$ \\
& {$[0.0533]$} & {$[0.0219]$} & {$[0.1056]$} & {$[0.0168]$} & {$[0.0219]$} & {$[0.0355]$} \\
YG & & 0.0346 & & 0.1281 \\
& & & {$[0.2144]$} & & {$[0.0698]$} \\
LNZZC & $-0.0300^{* * *}$ & $-0.0145^{* *}$ & $-0.0312^{* * *}$ & $-0.0184^{* * *}$ & $-0.0145^{* *}$ & $-0.0137^{* * *}$ \\
& {$[0.0135]$} & {$[0.0067]$} & {$[0.0139]$} & {$[0.0042]$} & {$[0.0067]$} & {$[0.0033]$} \\
CAR & 0.1190 & 0.0131 & 0.1397 & $0.1088^{* * *}$ & 0.0131 & $0.0692^{* * *}$ \\
& {$[0.1100]$} & {$[0.0581]$} & {$[0.1149]$} & {$[0.0397]$} & {$[0.0581]$} & {$[0.0271]$} \\
NPLR & 0.2262 & $-0.2910^{*}$ & 0.2518 & $-0.1710^{*}$ & $-0.2910^{*}$ & $-0.1716^{* * *}$ \\
& {$[0.3167]$} & {$[0.1532]$} & {$[0.3294]$} & {$[0.0915]$} & {$[0.1532]$} & {$[0.0627]$} \\
LNGDP & 0.0186 & $-0.0955^{* * *}$ & 0.0185 & -0.0058 & $-0.0955^{* * *}$ & -0.0000129 \\
& {$[0.0473]$} & {$[0.0204]$} & {$[0.0503]$} & {$[0.0112]$} & {$[0.0204]$} & {$[0.0104]$} \\
constant & 0.2697 & $1.3039^{* * *}$ & 0.2893 & $0.3564^{* * *}$ & $1.3039^{* * *}$ & $0.2199^{* * *}$ \\
& {$[0.3949]$} & {$[0.1896]$} & {$[0.4468]$} & {$[0.0974]$} & {$[0.1896]$} & {$[0.0960]$} \\
\hline
\end{tabular}

Note: Standard errors are reported in the square brackets. *, **, *** indicate significance level at $10 \%, 5 \%$ and $1 \%$, respectively.

Table 4. Sobel Test Results

\begin{tabular}{ccc}
\hline & $(1)$ & $(2)$ \\
\hline z statistics & 0.1614 & 1.8269 \\
two-tail probability & 0.8718 & 0.0677 \\
\hline
\end{tabular}

\subsection{Direct Effect of DOI on Overseas Performance}

Hypothesis $1 \mathrm{a}$ and $1 \mathrm{~b}$ estimate the direct impact of banking internationalization on its overseas performance. Hypothesis1a suggests that DOI has a positive direct effect on the performance of overseas deposit and loan business. In formula (3), the DOI coefficient is positive and significant at the significance level of $1 \%$, which indicates that DOI has a direct positive effect on the performance of overseas deposit and loan business, namely, 
the improvement of DOI is conducive to the performance of overseas deposit and loan business. This result supports hypothesis 1a. DOI also has a positive direct effect on the overseas performance of the intermediate business. In formula (6), the coefficient of DOI is significantly positive at $1 \%$ level, which means that DOI also has a positive direct effect on the performance of the overseas intermediate business, namely the improvement of DOI will promote the performance of the overseas intermediate business. Thus hypothesis $1 \mathrm{~b}$ is also supported.

\subsection{The Positive Influence of DOI on Staff Localization}

Hypothesis 2 suggests that DOI has a positive effect on staff localization. In formula (2), the coefficient of DOI is positive and significant at the significance level of $1 \%$, which means that DOI is positively correlated with the localization of staff. This result supports hypothesis 2 .

\subsection{Intermediary Effect of Staff Localization}

Hypothesis $3 \mathrm{a}$ and $3 \mathrm{~b}$ estimate the intermediary role of staff localization in banking internationalization and overseas performance. Assume that $3 \mathrm{a}$ indicates that the localization of staff does not play a significant role in business internationalization and overseas deposit and loan business performance. In accordance with the inspection steps of intermediary effect, because DOI coefficient in formula (1) is significant, and one of DOI coefficient in formula (2) and staff localization coefficients in formula (3) is significant, there is step 3, namely Sobel inspection. The results are shown in Table 5 column (1). The statistic is not significant at the significance level of $10 \%$.Then $3 \mathrm{a}$ is supported. Hypothesis $3 \mathrm{~b}$ believes that the localization of staff plays a intermediary role between DOI and the performance of overseas business. In accordance with the inspection steps of intermediary effect, because the DOI coefficient of DOI is significant and one of the DOI coefficient in formula (5) and the staff localization coefficient in formula (6) is significant, go to step 3, namely Sobel inspection. The results are shown in table 5 column (2), and the statistic is significant at the significant level of $10 \%$, which means there is an intermediary effect. Meanwhile, as the regression coefficient of DOI in formula (6) is positive at the significance level of 5\%, staff localization has an intermediary effect between DOI and the performance of overseas deposit and loan business, namely DOI has an indirect positive effect on overseas intermediate banking business through an impact on staff localization behaviors. Thus, hypothesis $3 \mathrm{~b}$ is supported.

\subsection{The Influence of Other Control Variables}

In formula (3) and (6), the bank's own control variables (Total bank assets) are significantly negative on the significance level of 5\% and $1 \%$ respectively, as shows that total bank assets are negatively related to overseas performance of both deposit/lending and intermediary businesses. That is to say, the larger the bank size, the lower its overseas performance. This may be because as far as Chinese banks' internationalization level, large size will cause the loss of flexibility to adjust business strategy to adapt to the external environment, which is bad for its overseas deposit/lending and intermediary business performance improvements.

In formula (6), the control variable of the bank, the capital adequacy ratio of the bank, is significantly positive at the significance level of 5\%. It shows that the capital adequacy ratio is positively correlated with the overseas performance of intermediary business of the bank, that is, the higher the capital adequacy ratio, the higher the overseas performance of intermediary business. This may be because the stronger the bank's ability to resist risks, the easier it take measures to promote the development of its overseas intermediary business, thereby improving performance.

In formula (6), the control variable of the bank, the non-performing loan ratio of bank, is significantly negative at the significance level of $1 \%$. It shows that the non-performing loan ratio is negatively correlated with the overseas performance of intermediary business of the bank, namely, the higher the non-performing loan ratio, the lower the performance of the overseas intermediary business. This may be because banks face rising credit risks that slow down the intermediary business when the quality of their loans deteriorates.

In formula (2), the macro level of control variables (G20 GDP) is significantly negative at the significance level of $1 \%$. This indicates that the external macroeconomic situation is negatively correlated with staff localization, namely at the economic downturn of the host country, and the increase of the local staff employed by the bank. This may be because when the host country economic development slowdown, the market risk for bank management will rise, in the face of tough economic times, banks tend to recruit more local staff familiar with local market environment.

\section{Endogeneity and Robustness Test}

\subsection{Endogeneity Test}

The assumption of Sobel test is that there is no inverse causality between the intermediate variables and the 
dependent variables, the independent variables and the dependent variables, and there are no missing variables in the regression. In order to ensure that the localization of employees plays the role of intermediary effect between DOI and overseas performance, it is necessary to test endogeneity of the model.

Walid and Eric (2009) employs the lag phase of performance as a tool variable to explore whether there is a reverse causal relationship between internationalization and performance, namely whether better banks prefer internationalization. In this way, the paper selects the overseas performance of bank's intermediary business in lag phase 1 and 2 as tool variables, to test whether endogenous problems existing in formula (4) and (6) by Davidson-MacKinnon test. The results are shown in Table 5.

Table 5. Davidson-MacKinnon Test Results

\begin{tabular}{ccc}
\hline & $(1)$ & $(2)$ \\
\hline F statistics & 0.3181 & 0.5551 \\
P value & 0.5761 & 0.4610 \\
\hline
\end{tabular}

Column (1) in Table 6 reports the results of endogeneity test in formula (4), and the F statistical value was insignificant, accepting the original hypothesis that the IV regression was not significantly different from the original regression. Column (2) reported the results of endogenous test in formula (6), and the F statistical value was not significant, and the original hypothesis was accepted that there was no significant difference between the IV regression and the original regression. This indicates that there is no inverse causal relationship between DOI and the overseas performance of bank's intermediary business, between staff localization and the overseas performance of bank's intermediary business. The indirect effect of DOI on staff localization, thus the overseas performance of the intermediary business is significant.

\subsection{Robustness Test}

To test the robustness of mediation effect, this paper introduces the portion of overseas institutions' number as proxy variable, to measure DOI, and the intermediary effect was retested according to the above steps. Results are shown in Table 6.The Sobel test results are shown in Table 7. The test results are basically consistent with the previous ones, which further support hypotheses $\mathrm{H} 1 \mathrm{a}, \mathrm{H} 1 \mathrm{~b}, \mathrm{H} 2, \mathrm{H} 3 \mathrm{a}$ and $\mathrm{H} 3 \mathrm{~b}$.

Table 6. Regression Results

\begin{tabular}{ccccccc}
\hline & $(1)$ & $(2)$ & $(3)$ & $(4)$ & $(5)$ & $(6)$ \\
\hline \multirow{3}{*}{ DOI } & PERF_LX & YG & PERF_LX & PERF_SX & YG & PERF_SX \\
& $0.7324^{* * *}$ & $1.4495^{* * *}$ & 0.2734 & $0.5584^{* * *}$ & $1.4495^{* * *}$ & 0.1934 \\
YG & {$[0.2485]$} & {$[0.0442]$} & {$[0.4867]$} & {$[0.0824]$} & {$[0.0442]$} & {$[0.2299]$} \\
& & & & & 0.2845 \\
LNZZC & & & & & {$[0.1720]$} \\
& $-0.0314^{*}$ & $-0.0066^{* * *}$ & $-0.0307^{*}$ & $-0.0150^{* *}$ & $-0.0066^{* * *}$ & $-0.0139^{* *}$ \\
CAR & {$[0.0183]$} & {$[0.0024]$} & {$[0.0179]$} & {$[0.0063]$} & {$[0.0024]$} & {$[0.0065]$} \\
& 0.0884 & -0.0054 & 0.0991 & $0.0941^{*}$ & -0.0054 & $0.0989^{*}$ \\
NPLR & {$[0.1401]$} & {$[0.0237]$} & {$[0.1420]$} & {$[0.0502]$} & {$[0.0237]$} & {$[0.0511]$} \\
& 0.4883 & -0.0029 & 0.237 & -0.1141 & -0.0029 & -0.1513 \\
LNGDP & {$[0.4794]$} & {$[0.0536]$} & {$[0.4860]$} & {$[0.1496]$} & {$[0.0536]$} & {$[0.1562]$} \\
& $0.1541^{* *}$ & $0.0210^{* * *}$ & $0.1335^{* *}$ & $0.0384^{*}$ & $0.0210^{* * *}$ & $0.0342^{*}$ \\
constant & {$[0.0672]$} & {$[0.0076]$} & {$[0.0648]$} & {$[0.0199]$} & {$[0.0076]$} & {$[0.0208]$} \\
& $-1.1995^{* *}$ & $-0.1253^{*}$ & $-0.9811^{*}$ & -0.1876 & $-0.1253^{*}$ & -0.1588 \\
\hline
\end{tabular}

Note. Standard errors are reported in the square brackets. ${ }^{*}, * *, * * *$ indicate significance level at $10 \%, 5 \%$ and $1 \%$, respectively.

Table 7. Results of Sobel Test

\begin{tabular}{ccc}
\hline & $(1)$ & $(2)$ \\
\hline z statistics & 1.4975 & 1.6520 \\
two-tail probability & 0.1343 & 0.0985 \\
\hline
\end{tabular}

\section{Conclusion}

This paper selects China's four major banks' (BOC, ABC, ICBC and CCB) semi-annual data from 2009 to 2015 as the research sample, attempts to build the panel model from the perspective of organizational reform, by introducing the intermediary variable, staff localization, and the refined measurement of overseas performance, to open the "black box" of bank's performance under the influence of internationalization degree and the 
systematically study the relations among the internationalization, staff localization and bank's overseas performance, and finally reveal the conduction path of performance change under the influence of overseas expansion. The results show that DOI has a direct positive effect on the overseas performance of the deposit/loan business, but the intermediary role of staff localization is insignificant. Moreover, the DOI has a direct positive effect on the overseas performance of the intermediary business, and staff localization plays a positive intermediary effect between DOI and the overseas performance of the intermediary business. At the same time, the more internationalized Chinese banks will be more aggressive in promoting staff localization.

There are two deficiencies in this paper due to the limited financial information of overseas institutions published by the bank. Because the intermediate business's revenues of overseas institutions cannot be subdivided into knowledge-intensive, labor-intensive and technology-intensive intermediate business revenue, it is hard to further analyze DOI indirectly influences staff localization through which specific module's overseas performance of intermediary business. This paper simply takes the local staff of the host country as a whole and does not distinguish administrative staff and ordinary business people. It is possible that the local staff of the management team will influence the internationalization performance of the bank from different paths.

For future research, the small and medium-sized joint-stock commercial banks which are in the progress of internationalization can be included in the sample, the comparative analysis of Chinese-funded banks which are in the different stage of internationalization and to study whether there is difference between staff localization's intermediary effect on internationalization and internationalization performance are necessary.

\section{References}

Aliber, R. Z. (1984). International banking: a survey. Journal of Money, Credit and Banking, 16(4), 661-678. https://doi.org/10.2307/1992100

Andres, P. D., Vallelado, E. (2008). Corporate governance in banking: The role of the board of directors. Journal of Banking \& Finance, 32(12), 2570-2580. https://doi.org/10.1016/j.jbankfin.2008.05.008

Baum J. A. C., \& Ingram, P. (1998). Survival-enhancing learning in the Manhattan hotel industry, 1898-1980. Management Science, 44(7), 996-1016. https://doi.org/10.1287/mnsc.44.7.996

Chen, F. (2015). Impact of non-interest income business in Chinese commercial Banks. (Doctoral dissertation). Liaoning University, Shenyang, China

Chen, M. H., Wu, J., Bang, N. J., \& Wang, R. (2017). Do foreign banks take more risk? Evidence from emerging economies? Journal of Banking and Finance, 82, 20-39. https://doi.org/10.1016/j.jbankfin.2017.05.004

Deng Y. X. (2008). Research on "customer follow" effect in the internationalization of commercial Banks in China. (Doctoral dissertation). Huazhong University of Science \& Technology, Wuhan, China

Driscoll, J. C., \& Kraay, A. (1998). Consistent Covariance Matrix Estimation With Spatially Dependent Panel Data. Review of Economics and Statistics, 80(4), 549-560. https://doi.org/10.1162/003465398557825

Eden, L., \& Miller, S. (2004). Distance matters: Liability of foreignness, institutional distance and ownership strategy. In Hitt, M., \& Cheng, J. (Eds.). The evolving theory of the multinational firm. Advances in international management, 16, 187-221. Amsterdam: Elsevier. https://doi.org/10.1016/S0747-7929(04)16010-1

Feng, S. Q, (2003). An empirical study on the internationalization and financial development of the bank. International Financial Research, 12, 43-47.

Guo, Z. Q. (2008). Internationalization of commercial Banks: challenges and strategies. Western Finance, 11, 12-13.

Guo, Z. Y. (2017). Comparison of Error Correction Models and First-Difference Models in CCAR Deposits Modeling, Global Journal of Management and Business Research, 17(3), 13-31. https://doi.org/10.2139/ssrn.3013799

Walid, H., \& Eric, S. (2010). Foreign asset risk exposure, DOI, and performance: An analysis of Canadian banks. Journal of International Business Studies, 41(5), 845-860. https://doi.org/10.1057/jibs.2009.86

Huang Y. (2011). Research on the motivation and effect of foreign Banks into Chinese banking. (Doctoral dissertation). Southwestern University of Finance \& Economics. Chengdu, China

Huang, Y., \& Sternquist, B. (2007). Retailers' foreign market entry decisions: An institutional perspective. International Business Review, 16, 613-629. https://doi.org/10.1016/j.ibusrev.2007.06.005 
Hymer, S. (1976). The international operations of national firms: A study of foreign direct investment. Cambridge, MA: MIT Press.

Jing, L. X. (2011). The influence factors and the empirical study on the localization of small and medium Korean enterprises in central China. (Doctoral dissertation). Fudan University. Shanghai, China.

Liang H. Y., Ching Y. P., \& Chan K. C. (2013). Enhancing bank performance through branches or representative offices? Evidence from European banks. International Business Review, 22(3), 495-508. https://doi.org/10.1016/j.ibusrev.2012.07.003

Liu, A. L. (2007). Empirical study on the factors of internationalization of commercial Banks in China. (Doctoral dissertation). Zhejiang University. Hangzhou, China.

Liu, M. F., Zhang, X. L., \& Zhang, C. (2012). China's commercial banking diversification, operating performance and risk correlation research. International Finance Research, 8, 59-69.

Miller, S. R., \& Parkhe, A. (2002). Is there a liability of foreignness in global banking? An empirical test of banks' X-efficiency. Strategic Management Journal, 23, 55-75. https://doi.org/10.1002/smj.212

Qi, S. T. (2008). Commercial bank performance, efficiency and market structure-based on Chinese panel data from 1994 to 2005. International Finance Research, 3, 48-56.

Sobel, M. E. (1982). Asymptotic Confidence Intervals for Indirect Effects in Structural Equation Models. Sociological Methodology, 13, 290-312. https://doi.org/10.2307/270723

Sun, W., Wang, Z., \& He, B. (2006). The evolution trend of commercial bank performance and its formation mechanism - empirical study on mixed data from 1996 to 2002. Financial Research, 10, 53-63.

Wan, W. P., Yiu, D. W., \& Hoskisson, R. E. \& Kim, H. (2008). The performance implications of relationship banking during macroeconomic expansion and contraction: a study of Japanese banks' social relationships and overseas expansion. Journal of International Business Studies, 39(3), 406-427. https://doi.org/10.1057/palgrave.jibs.8400364

Wang, Q., Wu, W., \& Huang, J. (2012). Cross-regional operation of urban commercial Banks: credit expansion, risk level and bank performance. Financial Research, 1, 141-153.

Wang, T. K., \& Feng, S. Q. (2007). The transformation and internationalization of commercial Banks in China. Shanxi Economics Press. Taiyuan, China.

Wei, J., \& Zheng, D. S. (2010). Research on localization of human resource management and enterprise performance relationship in hk-funded enterprises. Science and Technology Management, 31(10), 192-199.

Wen, Z. L., Zhang, L., \& Hou, J. T. (2004). The mediation effect inspection procedure and its application. Journal of Psychology, 36(5), 614-620.

Xiong, F., Wang, N., \& Zhang, H. Y. (2014). The internationalization of large commercial Banks in China and its performance. Financial BBS, 7, 39-44.

Ye, A. C. (2010). Determinants of global integration and localization strategy of multinational companies in China and its impact on performance. (Doctoral dissertation). Fudan University. Shanghai, China.

\section{Copyrights}

Copyright for this article is retained by the author(s), with first publication rights granted to the journal.

This is an open-access article distributed under the terms and conditions of the Creative Commons Attribution license (http://creativecommons.org/licenses/by/4.0/). 